\title{
El sueño moderno de devenir Otro: tras los pasos de Artaud en la Sierra Tarahumara
}

\author{
The Modern dream of Becoming Other: \\ Following the Footsteps of Artaud in the Sierra Tarahumara
}

\author{
VARINIA NieTO SÁNCHEZ \\ Universidad de Barcelona, Despartamento Lenguas \\ y Literaturas Modernas y Estudios Ingleses \\ varinians@yahoo.com
}

\begin{abstract}
RESUMEN: Los puntos centrales alrededor de los cuales gira este artículo son el viaje de Artaud a México en 1936 y sus relecturas posteriores, así como las relaciones que sugiere la idea del sueño en este recorrido histórico e interdisciplinario. Primero, "el sueño tarahumara" de Artaud que pone en tela de juicio la identidad del sujeto moderno. Años más tarde y en el contexto de la posmodernidad, J. M. G. Le Clézio escribe el texto "Antonin Artaud ou le rêve mexicain" y aborda el sueño mexicano desde la transculturalidad y la crítica de Occidente. Paralelamente, guiados por los textos de Artaud, los cineastas Raymonde Carasco y Régis Hébraud realizan entre 1976 y 2003 una serie de películas sobre los tarahumaras y sobre el sueño chamánico desde una mirada poética, antropológica y filosófica.
\end{abstract}

Palabras Clave:

Artaud y tarahumaras;

literatura y cine; sueño chamánico; identidad cultural; geopoética.
KEYWORDS:

Artaud and Tarahumaras; Literature and Cinema; Shamanic Dream; Cultural Identity; Geopoetics.
ABSTRACT: The central points around which this article revolves are Artaud's trip to Mexico in 1936, and its subsequent re-readings, as well as the relationships suggested by the idea of the "dream" in this historical and interdisciplinary journey. First, "the Tarahumara dream" of Artaud that questions the identity of the modern subject. Years later and in the context of postmodernity, J. M. G. Le Clézio writes the text "Antonin Artaud ou le rêve mexicain" (Antonin Artaud or the Mexican dream) and addresses the "Mexican dream" from the cross-culturalism and criticism of the West. In parallel, and guided by the texts of Artaud, the filmmakers Raymonde Carasco and Régis Hébraud made between 1976 and 2003 a series of films about the 
Tomando como hilo conductor el viaje de Artaud a México en 1936, propongo abordar una genealogía del sueño mexicano en el escenario cultural francés del siglo xx y en las fronteras de distintas disciplinas como son la literatura, la filosofía y el cine. Artaud, poeta y hombre de teatro, Le Clézio, escritor y viajero, Raymonde Carasco y Régis Hébraud, cineastas e intelectuales; todos ellos viajan a México en busca de la posibilidad poética de ser Otro a través de una elaboración del poder y del ejercicio del sueño. Sueño del que destaco sobre todo su calidad poética y antropológica.

Este artículo parte de una ponencia y un texto presentados para el XXVII Coloquio de la Asociación de Francesistas de la Universidad Española que se llevó a cabo en mayo de 2018 en la Universidad de Sevilla. Debido a los límites establecidos sobre la extensión de los trabajos, tuve que ser muy puntual en el desarrollo del tema por lo que el presente artículo ambiciona profundizar en él y así dar cuenta de una forma más detallada de los avances de mi investigación de estancia posdoctoral. Cabe señalar que este texto se desarrolló en el marco del programa de doctorado de Construcción y Representación de Identidades Culturales de la Facultad de Filología de la Universidad de Barcelona. Mi interés se centró precisamente en la forma en que las relecturas de los textos de Artaud representaron para una generación posterior una pregunta y una crítica sobre la identidad del ser humano occidental que seguía vigente en la posmodernidad. En este sentido, no me enfoqué en estudios rigurosamente filológicos o históricos de los textos y del viaje de Artaud. ${ }^{1}$ El mismo Artaud fue bastante heterodoxo en la consulta de sus fuentes e imaginativo en la interpretación de éstas y de los ritos que presenció. Su visión de los tarahumaras ha sido criticada por es-

1 Me refiero principalmente al prólogo de Luis Mario Schneider (2004b); los artículos de Enrique Flores (1999; 2005); los textos escritos por Évelyne Grossman para las OEuvres de Artaud (2004a), y el libro de Armando Pereira (2011). 
pecialistas en antropología, historia o etnología. ${ }^{2}$ Él mismo reconoció que, basándose en sus lecturas de historia sobre las antiguas culturas mexicanas, se permitió soñar como poeta sobre lo que ésta no enseña (Artaud 2004a: 720). Así, trabajé relecturas, por un lado, más abiertas en el sentido de que traspasaban los límites establecidos por las áreas del conocimiento desde una visión interdisciplinaria y multicultural y, por otro lado, condicionadas por un contexto histórico y cultural determinado. ${ }^{3}$ Las investigaciones y obras de Artaud, Le Clézio, Carasco y Hébraud tienen entre ellas un elemento en común que deseo resaltar. No sólo se alimentan de otros textos literarios o de fuentes históricas, antropológicas, etnográficas, psicoanalíticas y filosóficas, sino también de la observación y de la experiencia directa sobre el terreno. Al establecer un hilo entre ellas, pretendo destacar la visión poética como una forma de crear o configurar identidades posibles cuyo trayecto hunde sus pasos en un territorio y en una suerte de trabajo de campo donde los rituales observados y vividos son proyectados a otro sitio en el que son desacralizados de su sentido más estricto y recontextualizados a la luz de otras preocupaciones y realidades.

En "Antonin Artaud ou Le rêve mexicain", Le Clézio describe México como una tierra de sueños y se pregunta por el principio mismo de este sueño mexicano:

Le Mexique est une terre de rêves. Je veux dire, une terre faite d'une vérité différente, d'une réalité différente. Pays de lumière extrême, pays de violence, où les passions essentielles sont plus visibles et où la marque de l'antique histoire de l'homme est plus sensible; tout comme dans certains pays fabuleux, la Perse, l'Égypte, la Chine. Pourquoi ce rêve ? qu'est-ce qui fait du Mexique un des lieux privilégiés du mystère, de la légende, un lieu où le moment même de la création paraît encore proche alors que déjà s'annonce, inexplicablement, l'autre moment suprême, celui de la destruction du monde? (Le Clézio 2000: 214). ${ }^{4}$

2 Sobre el discurso primitivista y fantasioso de Artaud remito, a modo de ejemplos, a Acuña Delgado (2009); Sariego Rodríguez (2002) y Todorov (2007: 383-386).

3 En los años sesenta se reinterpretan significativamente los textos de Artaud, a través de los trabajos de Maurice Blanchot, Jacques Derrida, Julia Kristeva, Philippe SoIlers, Gilles Deleuze y Félix Guattari, muchos de ellos reunidos en la revista Tel Quel.

4 "México es un país de sueños: quiero decir, un país hecho de una verdad diferente, de una realidad diferente. Es un país de luz exagerada, un país de violencia en el que las pasiones básicas son más visibles y en el que la marca de la historia antigua 
Le Clézio ubica en la Francia del siglo xIx el resurgimiento de este sueño. La idea pueril e idílica del buen salvaje que vive en la naturaleza virgen del Nuevo Mundo propia del periodo romántico se verá modificada, entre otras razones, gracias a las obras y viajes del abad Brasseur de Bourbourg, ${ }^{5}$ quien exploró entre 1848 y 1863 el territorio que abarca desde Guatemala hasta California apoyado por Napoleón III. También gracias a los escritos de Michel Chevalier ${ }^{6}$ quien viajó en 1835 a México con la misión de explorar los intereses materiales y económicos franceses en esta región. Sus obras mostraron a los lectores el poder de la magia y del imaginario de los pueblos indígenas que no desaparecieron con la colonización.

Más allá de los sueños de poder y riqueza de Napoleón III, las tierras mexicanas también despertaron el sueño de un mundo diferente y renovado. Esta fascinación tenía su referente en los pueblos sobrevivientes de la colonización que seguían practicando la magia y los rituales y que conservaban, de una forma misteriosa y a veces muy cercana a la extinción, el saber de las antiguas culturas prehispánicas. Le Clézio observa que estos sueños no son manifestaciones gratuitas de la imaginación, sino que se relacionan con el poder del sueño que está en el corazón mismo de las civilizaciones precolombinas: sueños proféticos, sueños en los que los seres humanos entran en contacto con lo sagrado, sueños que anuncian la destrucción de su mundo. Le Clézio precisa: "Ce pouvoir de rêve conduit à l'époque contemporaine sur ce que l'on peut appeler une renaissance de l'irrationnel" (2000: 217).7 En El retorno de lo real. La vanguardia a finales de sig/o, Hal Foster remarca que la pregunta sobre la identidad del sujeto moderno formulada a través de la apelación a la

del hombre es más evidente, exactamente como en algunos países fabulosos: Persia, Egipto y China. ¿Y este sueño, por qué? ¿Qué hace que México sea uno de los lugares privilegiados por el misterio y la leyenda, un lugar en el que el momento mismo de la creación todavía parece cercano, mientras que inexplicablemente se anuncia ya el otro momento supremo: el de la destrucción del mundo?" (Le Clézio 2008: 215).

5 El abad Brasseur de Bourbourg (1814-1874) publicó diversas obras sobre las antiguas culturas de México y Guatemala. En 1857 apareció Historia de las naciones civilizadas de México y Centroamérica y en 1866 Monumentos antiguos de México.

6 Michel Chevalier (1806-1879) publicó en 1837 Des Intérêts matériels en France y en 1863 Le Mexique ancien et moderne.

7 "Esta fuerza del sueño lleva a la época contemporánea a lo que podemos Ilamar el renacimiento de lo irracional" (Le Clézio 2008: 217). 
Otredad, ya sea el inconsciente o el Otro cultural y mediante los discursos del psicoanálisis y la antropología, representa un problema esencial de la modernidad (2001: 212). Así, el sueño mexicano que revalora al mundo indígena de los siglos XIX y $\mathrm{xx}$, asociado al reencuentro de un paraíso perdido para la civilización occidental y al uso del poder de la magia por los pueblos vencidos, atrajo a poetas franceses como André Breton ${ }^{8}$ y, quien nos ocupa, Antonin Artaud.

\section{Antonin Artaud y el sueño de aniquilación del sujeto moderno}

\subsection{El pensamiento sin palabras}

Desde sus inicios en la escritura literaria, Artaud se refiere a las dificultades que experimenta para expresar su pensamiento en palabras y propone que la atención sea puesta en ese movimiento doloroso de la creación que involucra el dominio imponderable de los afectos, los nervios, el cuerpo y el intelecto. En la correspondencia que mantiene con Jacques Rivière durante 1924, se describe alcanzado por una verdadera y profunda enfermedad del alma ${ }^{9}$ y no por un fenómeno de época. Se refiere a una enfermedad que afecta su mente, sus posibilidades de expresión, su alma y su carne: "Une maladie qui vous enlève la parole, le souvenir, qui vous déracine la pensée" (Artaud 2004a: 80). ${ }^{10} \mathrm{Y}$ entonces pregunta a su interlocutor: —¿Qué obra literaria sería compatible con semejante estado?

8 Le Clézio escribe en "Antonin Artaud o el sueño mexicano": "Muchos poetas han tenido este sueño, tanto en Francia como en México, y no por azar el sueño atrajo a México a uno de los más prestigiosos buscadores de sueños: el surrealista André Breton" (2008: 219). Por otra parte, en Diego y Frida, Le Clézio explica que André Breton viaja a México para reunirse con Trotski (1994: 186). Como señala Fabienne Bradu (2012), uno de los principales motivos para determinar la visita de Breton a México en 1938 fue su encuentro con Trotski, pero también hubo otros, como arreglos para impartir unas conferencias y conocer el país. Su visita también representaba una forma de regenerarse, ya que en Europa el movimiento surrealista estaba en declive.

9 En una de una carta del 25 de mayo de 1924, Artaud define el "alma" como la emanación de nuestra fuerza nerviosa coagulada en torno a los objetos (2004a: 79).

10 "Una enfermedad que te quita la palabra, la memoria, que te arranca el pensamiento" (la traducción es mía). 
Cuando ese mismo año se une al grupo surrealista, ${ }^{11}$ deja de buscar en el trabajo del pensamiento una continuidad y coherencia que no puede manifestar más que de una forma fallida, intermitente y dolorosa. Entonces busca en los sueños y en el delirio nuevas leyes. En "Manifeste en langage clair", publicado en La Nouvelle Revue Française en diciembre de 1925, Artaud declara: "Je me livre à la fièvre des rêves, mais c'est pour en retirer de nouvelles lois. Je recherche la multiplication, la finesse, I'œil intellectuel dans le délire, non la vaticination hasardée. II y a un couteau que je n'oublie pas" (2004a: 149). ${ }^{12}$ Sueño, delirio y lucidez. La revolución por la que luchan los surrealistas no sólo se limita a poner en práctica una nueva forma poética, sino también a buscar una transformación radical de las instituciones familiares, sociales, ideológicas y políticas que rige la vida de los franceses. Artaud define el surrealismo como una revuelta moral, un grito orgánico del ser humano que nació de la desesperanza y el disgusto (cfr. 2004a: 150-151). Dos años más tarde, cuando ya no forma parte de este movimiento, en "À la grande nuit ou le bluff surréaliste" (1927), reconoce el valor que mantiene el surrealismo para él y lo identifica con una suerte de magia donde la imaginación, los sueños, toda esa intensa liberación del inconsciente que hace aflorar lo oculto — también asociada al "pensamiento primitivo" — debía introducir transformaciones profundas en la escala de las apariencias, en el valor de sus significaciones y en el simbolismo creado. Señala: "Le concret tout entier change de vêture, d'écorce, ne s'applique plus aux mêmes gestes mentaux. L'au-delà, I'invisible repoussent la réalité. Le monde ne tient plus" (2004a: 238)..$^{13}$ Violencia y rechazo son los dos polos de un estado de espíritu imposible, declara Artaud en "Surrealismo y revolución" (2004b: 104). Su intención es romper con la realidad, confundir los sentidos, pero dentro de una noción de lo concreto que manifieste un estado orgánico o una exudación física de la inquietud del espíritu (2004b: 105).

11 Artaud formó parte del movimiento surrealista entre 1924 y 1926.

12 "Me libro a la fiebre de los sueños, pero es para extraer de ellos nuevas leyes. Busco la proliferación, la sutileza, el ojo intelectual en el delirio, no el vaticinio azaroso. Hay un cuchillo que no olvido" (la traducción es mía).

13 "Todo lo concreto cambia de vestido, de cascarón, ya no se aplica a los mismos gestos mentales. El más allá, lo invisible, rechaza la realidad. El mundo ya no se tiene en pie" (la traducción es mía). 
El sueño se burla de la razón, confunde los sentidos para devolverlos a su sentido profundo - nos dice Artaud. Conduce a un conocimiento de los fondos ocultos del ser humano. Para él, el surrealismo es "una crítica de los hechos y del movimiento de la razón dentro de los hechos" (2004b: 109). No apunta a una realidad superior, sino al trayecto que se establece entre lo real y el Yo. ${ }^{14}$ Así, esta idea del sueño implica variaciones y oscilaciones en las relaciones entre la realidad, lo real, el pensamiento, el cuerpo y el lenguaje. El inconsciente no está necesariamente asociado a lo azaroso e irracional, separado de la vida consciente y de la materia, sino que es fuente creativa de un nuevo orden a nivel formal que proyecta a través de un trabajo del intelecto otros gestos mentales, otras relaciones entre el lenguaje y las cosas en perpetuo movimiento entre el vacío y las formas. La integración del sueño en la realidad para ir más allá de la dualidad consciencia-inconsciencia formó parte de la renovación de la experiencia poética propuesta por el surrealismo.

Años más tarde, en 1935, este paso entre la nada y las formas se articula en una poética y en una búsqueda por reformular el lenguaje teatral mediante la utilización de diversos elementos del espacio escénico que ampliaran la capacidad expresiva del pensamiento más allá de las palabras. Artaud imagina un tipo de teatro capaz de desplegar y elegir su propio lenguaje en el espacio escénico: ya sea música, gestos, movimientos, palabras, gritos, luces; como si emulara un estado del sueño anterior a las palabras. En "El teatro de la crueldad", incluido en El teatro y su doble, Artaud insiste en la necesidad de romper la sujeción del teatro al texto y de recobrar la noción de una especie de lenguaje único a medio camino entre el gesto y el pensamiento (2001: 102). Para resarcir la fractura entre las cosas y las palabras, ideas o signos, propone captar las fuerzas que duermen en las formas. Estas formas no debían ser bellas sino útiles. Asocia la desaparición de estas fuerzas al realismo artístico. Imagina un teatro que se proyecta hacia el porvenir y hacia el pasado —un teatro primitivo y un paraíso perdido-; un teatro que busca volver a las formas originarias del lenguaje y a una práctica eficaz de los signos. En Antonin Artaud, le théâtre et le retour aux

14 A lo largo del texto me referiré a la "realidad" como aquello que parte de la percepción de la realidad aparente y a lo "real" como aquello que existe independiente de la percepción y del pensamiento, totalidad compleja y dinámica. 
sources, Monique Borie señala que, mediante la vuelta a una eficacidad de lo simbólico, Artaud busca un estatus existencial regenerado que desborda los límites de la individualidad y cree en una fuerza unificadora fundada en un simbolismo mágico basado en la intuición de una unidad temporal y espiritual del mundo. Así, los símbolos no sólo están destinados a decir algo coherente sobre la naturaleza y la vida humana, sino que son también un instrumento de poder, herramientas para entrar en contacto con las fuerzas de la naturaleza (Borie 1989: 25-27). Artaud concibe un teatro que funciona como instrumento terapéutico, cercano al fin curativo de las ceremonias rituales. El director actúa como un chamán, manipula fuerzas cósmicas a partir de una puesta física y material de la escena.

En este contexto, el teatro como rito está desconectado de su aspecto propiamente religioso, pero permanece cargado de un mana poético que lo mantiene vinculado a lo sagrado. En relación con el teatro de la crueldad de Artaud y en Théâtre et cruauté ou Dionysos profané, Pierre Brunel apunta a que el mana poético sustituye el contenido sagrado de los mitos antiguos y ritos. Lo sagrado primitivo reenvía a la poesía moderna y a la idea de que la poesía todavía está contenida en las cosas (1982: 109-110). Este sagrado se aloja en la multiplicidad, la contradicción, el desorden y, simultáneamente, en la unidad de todas las cosas. Como señala Mircea Eliade en "Permanencia de lo sagrado en el arte contemporáneo", es en los sueños y en los sueños de vigilia o en sus distracciones, nostalgias y pulsiones donde el ser humano moderno no religioso ${ }^{15}$ continúa participando de lo sagrado (2005: 141). Destaca el deseo del artista de "liberarse de la superficie de las cosas", de destruir las formas tradicionales —en este caso el teatro- para penetrar en la materia y desvelar sus estructuras íntimas, otorgando una interpretación religiosa "no tradicional" a los modos elementales de la materia. El artista busca recuperar una religiosidad arcaica y una sacralización de la naturaleza, ahí donde el occidental la ha convertido en un "objeto". Así, Eliade señala: "Se podría sostener que, en efecto, desde hace tres generaciones, asistimos a una serie de 'destrucciones' de mundos (es decir, de universos artísticos tradicionales) valerosa y a veces salvajemente emprendidas, con el fin de poder recrear o reencontrar

15 Eliade se refiere a la "muerte de Dios" enunciada por Nietzsche en 1880. 
un universo otro: nuevo y 'puro', no corrompido por el tiempo y la historia" (2005: 143). El teatro - como ciertos ritos cósmicos- debía ser capaz de regenerar las formas y el mundo por medio de su aniquilación, por medio de la reactualización provisional del caos. El desorden, así como la enfermedad, son revelación de lo invisible y posibilidad de purificación. Para Artaud, el teatro como medio terapéutico serviría para curar una cultura europea enferma.

Artaud creía que por su proximidad con los principios esenciales que le transmitían poéticamente su energía, el lenguaje del teatro debía transgredir los límites ordinarios del arte y la palabra (2001: 14). En el prefacio a El teatro y su doble, Artaud alude a las figuras en piedra talladas por los antiguos mexicanos y plantea que en esta cultura no se puede hablar de arte en el sentido occidental. Se refiere a un arte europeo muerto, de formas fijas y que no tiene ninguna utilidad práctica ni capacidad para captar las fuerzas vitales (2001: 12-14). Mientras que —escribe— "Ios mexicanos captan el Manas, las fuerzas que duermen en todas las formas, que no se liberan si contemplamos las formas como tales, pero que nacen a la vida si nos identificamos mágicamente con esas formas" (2001: 13). Las imágenes poéticas debían actuar como los sueños y no como copias de la realidad; ya que debían ser capaces de crear una nueva forma de pensar la realidad y de permitir al público liberar esta actividad mágica del sueño en un plano interior. Para Artaud, creer que el teatro tiene una función psicológica o moral y que los sueños tienen una función sustitutiva, es disminuir el alcance poético profundo de los sueños y del teatro. Así escribe: "Cuando todo nos impulsa a dormir, y miramos con ojos fijos y conscientes, es difícil despertar y mirar como en sueños, con ojos que no saben ya para qué sirven, con una mirada que se ha vuelto hacia dentro" (2001: 14).

Después de escribir El teatro y su doble y para seguir explorando las posibilidades de un teatro y un sueño que no estuvieran separados de la vida, Artaud proyectó un viaje a México. Antes de partir se documentó ampliamente y confiesa que, basándose en sus estudios de historia sobre las antiguas culturas mexicanas, se ha permitido soñar como poeta sobre lo que ésta no enseña (2004a: 720). Sus fuentes documentales son variadas, ya sea de orden histórico, etnológico e incluso esotérico (Flores 1999). Basándose en sus lecturas de Platón, Ficino, Kircher, Blavatsky, 
entre otros, Artaud sugiere una relación entre los antiguos pobladores de México, los Atlantes y el esoterismo egipcio fundada en un conocimiento del culto solar. En México, la verdad del mito y del rito se manifestarían - a sus ojos - en la geografía y en la realidad de esta cultura. Él deseaba recorrer un espacio físico con el fin de extraer sus secretos y hacer una investigación sobre el terreno y sobre sus fuentes vivas; esto es, sobre los ritos, las creencias, las fiestas y las costumbres de los pueblos autóctonos. Así como las huellas de los orígenes permanecen inscritas en el inconsciente del ser humano, también subsisten en la naturaleza y en las formas y símbolos de otras culturas.

\subsection{El sueño de Artaud: el rito del peyote}

Para Artaud, el deber del México moderno consistía en desarrollar su propia cultura y su propia ciencia. Sin embargo, al llegar a México en febrero de 1936 se encontró con un tipo de revolución distinta a la que había imaginado. El gobierno mexicano de aquella época buscaba "civilizar" y "alfabetizar" a los indígenas. Por ello, después de una estancia de varios meses en la Ciudad de México y de participar activamente en su vida intelectual, ${ }^{16}$ decidió partir a finales de agosto de 1936 a la Sierra Tarahumara para buscar a aquellos pueblos que no habían perdido el contacto con las fuerzas naturales, a aquellos ejecutores $-\mathrm{y}$ no precisamente artis-

16 Durante su estancia en la Ciudad de México, Artaud dictó conferencias y escribió varios artículos en periódicos nacionales que aparecen en el libro México y Viaje al país de los tarahumaras (2004b). En ellos, expuso sus ideas sobre el arte, el teatro, la civilización y la cultura, las antiguas culturas mexicanas, la magia, sus críticas al surrealismo y al ser humano occidental, así como a obras de artistas mexicanos. El prólogo de Luis Mario Schneider da cuenta de forma detallada sobre el viaje y los textos de Artaud. Éstos son imprescindibles para entender sus ideas, las intenciones de su viaje y forman parte de las referencias básicas de cualquier investigación sobre el tema, por lo que su lectura forma parte de mi bagaje. El hecho de que excluya esta parte de la estancia de Artaud no se debe a una falta de interés o a una desatención, sino a los objetivos que me he planteado tratar en este artículo y que he expuesto anteriormente. Me refiero a la relación entre la identidad personal, el sueño chamánico, el cuerpo y la poesía que manifiesta Artaud en "El rito del peyote entre los tarahumaras", que es reinterpretada posteriormente por Le Clézio en El sueño mexicano o el pensamiento interrumpido y en las películas Ciguri 99. Le dernier chaman y Raspador/le sueño de la serie La fêlure du temps de Carasco y Hébraud. 
tas- que conocían el lenguaje y los gestos que los mantenían en contacto con las fuentes vivas de la creación. Artaud quería estudiar los ritos y las danzas de los tarahumaras, iniciarse en el rito del peyote y comprobar en otra realidad distinta a la suya la práctica de sus ideas sobre la cultura, la vida, la poesía y el teatro. Allí permaneció aproximadamente un mes y medio. Para él, los ritos de este pueblo eran una manifestación directa de las fuerzas naturales que dormían en estas tierras, una expresión del teatro de la crueldad y podían servir para renovar el alma enferma del ser humano occidental moderno. De los textos que escribe sobre este viaje, "El rito del peyote entre los tarahumaras" es el sueño de Artaud, su relato e iniciación al rito. Compone una primera versión en el manicomio de Rodez en 1943, después de seis años de internamientos en distintos centros de salud mental, en forma de una carta dirigida al doctor Ferdière y con la idea de que formara parte de un libro que Henri Parisot deseaba publicar. El texto no aparece hasta finales de 1947 en la revista L'Arbalète en una versión corregida, en la que Artaud suprime las alusiones al doctor Ferdière y a la religión cristiana.

En "El rito del peyote entre los tarahumaras", Artaud explica que después de varios intentos y días de espera logró finalmente ponerse en contacto con los sacerdotes de Ciguri, quienes se ocupan de llevar a cabo el rito del peyote. Aclara que no reproduce en su texto las palabras de los sacerdotes al pie de la letra, sino reconstruidas bajo las iluminaciones fantásticas de Ciguri; es decir, desde su propia experiencia del rito y de los efectos del peyote. Artaud cuenta que recibió del "jefe de todas las cosas", quien gobierna las relaciones sociales entre los tarahumaras, un golpe de cuchillo entre el bazo y el corazón. Con este gesto tuvo la impresión de despertar a algo para lo que, hasta ahora, había sido un mal nacido. Nadie puede ser iniciado y recibir la unción de los sacerdotes del Tutuguri, cuya acción se refiere a las relaciones del alma con el Uno o el Sol, ni el golpe de inmersión y de incorporación de los sacerdotes de Ciguri, si no ha sido tocado por el cuchillo del "jefe de todas las cosas". Explica:

Y además es el orden jerárquico de las cosas el que determina que después de haber pasado por el TODO, es decir, lo múltiple, que son las cosas, uno retorne a la simplicidad de lo Uno, que es el Tutuguri o el Sol, para luego disolverse 
y resucitar por medio de esta operación de reasimilación misteriosa. Digo de reasimilación tenebrosa que está incluida en el Ciguri, como un Mito de reanudación, luego de exterminación, y por último de resolución en la criba de la expropiación suprema, tal como no cesan de gritarlo y de afirmarlo los sacerdotes en su Danza de toda la Noche (Artaud 2014: 10).

Para Artaud, el rito del peyote constituye una operación de aniquilamiento del Yo y de asimilación en la entidad sin dios, en lo infinito. Esta operación de disolución es reflejo de la continua auto-creación del Yo a partir de la nada. Estas ideas, formuladas a partir de sus conversaciones con algunos tarahumaras, fueron reafirmadas en la danza y puesta en escena del rito que presenció durante toda la noche. Artaud percibe figuras, ya sea realizadas por los danzantes, por los gestos del sacerdote o en la disposición de los elementos contenidos en el espacio sagrado, que sugieren la acción de principios que se entrechocan, luchan, se eluden y se emparejan. A su modo de ver, son como ideas inmateriales que toman su propio cuerpo y permanecen suspendidas y volátiles fuera del Ser, en lo infinito (Artaud 2014: 21). Como un sueño inmemorial de retorno al origen y luego al paso entre el vacío y la materialización de las formas, la muerte y la vida, la destrucción y la creación, la nada y la diferenciación de principios. Los sacerdotes del peyote —observa Artaud - ya no conocen el significado de los gestos de la danza, las actitudes y las figuras que trazan en el aire, pero obedecen a una especie de tradición física y a las órdenes secretas que les dicta el peyote.

Artaud nota que los indígenas tienen otra noción del cuerpo diferente a la de los occidentales. No se identifican plenamente con su cuerpo, lo perciben como una etapa transitoria, algunas veces como una carga, pero también como un refugio sin el que no podrían vivir. Artaud relata cómo, cierto día en que interrogaba a un tarahumara sobre el rito, al recitar éste una plegaria pudo ver cómo los sentimientos que irradiaban de él pasaban uno tras otro por su rostro sin que se apropiara de ellos por una emoción personal. Y continúa:

Un europeo jamás aceptará pensar que lo que ha sentido y percibido en su cuerpo, que la emoción que lo ha sacudido, que la extraña idea que acaba de tener y que lo entusiasmó con su belleza no era suya, y que otro ha sentido y 
vivido todo eso en su propio cuerpo, o de lo contrario se creería loco y uno se vería tentado a decir de él que es un alienado. El tarahumara, en cambio, distingue sistemáticamente entre aquello que es de él y aquello que es del Otro en todo lo que piensa, siente o crea. Pero la diferencia entre un alienado y él es que su conciencia personal se acrecienta en este trabajo de separación y de distribución interna, al que lo ha conducido el Peyote, y que refuerza su voluntad (Artaud 2014: 15).

Artaud percibe como si Otro viviera y sintiera en el cuerpo de los adeptos al rito de Ciguri, como si fuerzas que circulan tanto en el universo como en el ser humano se manifestaran en sus cuerpos. La concepción de sí que Artaud aprecia en el tarahumara, le proporciona esa imagen de una fuerza que sobrepasa al Yo y que se encarna en un cuerpo y en un alma y, gracias a la cual, el tarahumara siente que participa a la vez de lo uno y de lo múltiple. Esta concepción de la persona — como señala Monique Borie- se aleja de la del psicoanálisis, ya que el psiquismo y el cuerpo no están separados de aquello que los desborda, ni son susceptibles de ser transformados y curados sin recurrir a aquellas fuerzas que comparten con el universo. Éstas fundan a la persona y, a la inversa, ésta es indispensable para el mantenimiento de la vida mediante la práctica de los ritos y danzas. El sentimiento de pertenecer a lo ilimitado es lo que dará al Yo la posibilidad de reencontrar sus fuentes y sus propios límites. El psicoanálisis - observa Borie - no reenvía a ese tiempo de la cultura occidental donde todavía se tenía una visión unitaria y se creía en la unidad del cuerpo y del psiquismo, del ser humano y del universo. Es el Otro cultural quien ofrece la posibilidad de recorrer un camino de vuelta a las fuentes primitivas mediante el contacto con otra visión del ser humano y de sus relaciones con el mundo (1989: 109-111). Artaud profundiza en esta participación del ser humano en lo ilimitado como una experiencia de desposesión donde el cuerpo se expande fuera de sus límites, de sus órganos y gestos cotidianos.

Artaud expone en su relato una visión que tuvo bajo los efectos de Ciguri. En ese movimiento de repliegue del Yo en las aguas profundas describe la aparición de un vacío originario. Sin embargo, como nota Borie, su visión momentánea de plenitud desemboca en la imagen de una "raíz malograda" (1989: 188). Después de haber atravesado un desgarramiento y una angustia, Artaud se dice como "dado vuelta y revertido del otro lado 
de las cosas" (Artaud 2014: 25) por una fuerza terrible. Y prosigue: "Uno ya no siente el cuerpo que acaba de dejar y que lo asegura dentro de sus límites, en cambio se siente mucho más feliz de pertenecer a lo ilimitado que a sí mismo, pues uno comprende que lo que era sí mismo ha venido de la cabeza de eso ilimitado, lo Infinito, y que lo verá" (25). Entonces experimenta el cambio de su cuerpo y de la atmósfera a un estado gaseoso y acuático. De su bazo, hígado, corazón o pulmón se desprenden cosas que estallan en esa atmósfera. Artaud escribe:

Lo que salía de mi bazo o de mi hígado tenía la forma de las letras de un alfabeto muy antiguo y misterioso masticado por una enorme boca, pero espantosamente reprimida, orgullosa, ilegible, celosa de su invisibilidad; y esos signos eran barridos en todos los sentidos por el espacio, mientras que me pareció que yo ascendía por él, pero no por mí mismo. Ayudado por una fuerza insólita. Pero mucho más libre que cuando en la tierra yo estaba solo.

En un momento se alzó algo como un viento y retrocedieron los espacios. Del lado donde estaba mi bazo se excavó un vacío inmenso que se pintó de gris y rosa como la orilla del mar. Y en el fondo de ese vacío apareció la forma de una raíz malograda, una especie de J que tuviese en su cumbre tres ramas coronadas por una $\mathrm{E}$, triste y brillante como un ojo. Salían Ilamaradas de la oreja izquierda de la J, y pasando por detrás de ella parecían empujar todas las cosas hacia la derecha, del lado donde estaba mi hígado, pero mucho más allá de él. No vi más y todo se desvaneció, o fui yo el que se desvaneció regresando a la realidad ordinaria (Artaud 2014: 26).

Los sacerdotes del peyote mostraron a Artaud que el hígado era el filtro orgánico del Inconsciente: "Y es que en el hígado humano es donde se produce esa alquimia secreta y ese trabajo por el cual el yo de todo individuo elige lo que le es adecuado, lo adopta o lo rechaza entre las sensaciones, las emociones, los deseos que el inconsciente le forma y que componen sus apetitos, sus concepciones, sus creencias verdaderas y sus ideas" (2014: 29). A su entender, los fantasmas que afectan a la conciencia enferma no pertenecen al mundo de Ciguri y explica: "Tomar los propios sueños por realidades: allí es donde el Peyote nunca dejará que nos hundamos. O confundir percepciones tomadas de los bajos fondos fugitivos, incultos, no maduros todavía, que aún no se elevan del inconsciente alucinatorio, con las imágenes, las emociones de lo verdadero" (2014: 27-28). 
Sólo gracias a Ciguri, la conciencia puede abrirse a lo fantástico: "Y dicho fantástico es de noble calidad, su desorden es tan sólo aparente, obedece en realidad a un orden que se elabora en un misterio y en un plano que la conciencia normal no alcanza, pero que Ciguri nos permite alcanzar, y que es el misterio mismo de toda poesía" (2014: 28). Artaud llama la atención sobre un movimiento dinámico del pensamiento que no se queda en las formas o en el exterior. Nace en el vacío, va hacia lo pleno o concreto y vuelve al vacío. Para él, sentir este movimiento es entrar en contacto con el misterio de la poesía, fuerza mágica que le permite influir sobre la realidad (2004b: 120).

Artaud reconoce haber visto fantasmas y sufrido alucinaciones más tarde, durante el tiempo de sus internamientos, a causa de la desnutrición, el encierro y la aplicación de electrochoques. Cuando escribió "El rito del peyote entre los tarahumaras" ya se encontraba lejos de este tipo de curación y del pueblo que creía en ella. Después de lograr su propósito de participar en el rito del peyote regresó a Francia, publicó varios textos en periódicos mexicanos y estaba preparando un libro cuando fue encarcelado en Dublín por vagabundeo, repatriado a Francia e internado en distintos psiquiátricos. Al parecer sufría de exaltaciones místicas, alucinaciones y delirios de persecución que lo volvían violentamente antisocial y peligroso para el orden público.

\section{Relecturas y proyecciones del sueño de Artaud}

A mediados de los sesenta inicia una etapa de agitación en el contexto cultural europeo: movimientos estudiantiles, pacifistas, feministas, antipsiquiatría, crítica radical del poder, auge del postestructuralismo. En esta época, escritores como Blanchot, Foucault, Derrida, Kristeva o Deleuze realizan diversas relecturas de la obra de Artaud. Como señala Philippe Sollers, para esta generación que vivió tras un periodo de crisis marcado por dos guerras mundiales, el estalinismo y el fascismo, Artaud y Bataille se vuelven un signo de revolución porque atacaban a las religiones, al Estado, a la familia, a la Historia, al lenguaje, al saber, a las instituciones psiquiátricas y al pensamiento racional del sujeto moderno. Artaud y Ba- 
taille ponen en tela de juicio a la conciencia que les dio un estatuto de excéntricos y sus planteamientos tienen una repercusión importante en la ideología y en el vocabulario de esta generación posterior al 68 (cfr. Sollers 1977: 7-8). La "muerte del sujeto humanista" —prefigurada en las figuras de Dadá o del surrealismo- es enunciada por Foucault, Barthes, Derrida, Deleuze. Se abre un camino de salida —ya como tendencia más generalizada - fuera de la identidad personal y hacia al infinito de sentido fuera de uno. Évelyne Grossman —en su introducción a las CEuvresapunta a la proximidad de las ideas de Artaud con las nuestras, pensando en nosotros como sujetos post-identitarios que estamos menos determinados y seguros de la estabilidad de nuestras filiaciones y orígenes, así como de la determinación estrictamente local de nuestro cuerpo (cfr. Grossman 2004).

En El retorno de lo real. La vanguardia a finales de siglo, Hal Foster Ilama la atención sobre el hecho de que el Otro cultural, tras las guerras de liberación de las colonias francesas de los años cincuenta y sesenta, ya no es el mismo que el proyectado a mediados de los treinta, aunque se sigue utilizando como un espacio de escape ideológico para la racionalidad occidental. La "monocultura" ejercida por el Occidente capitalista se identifica en ese momento como la responsable de la violencia y marginación en que vive ese Otro cuya pureza se ha perdido. Visión fatalista de un mundo exótico cerca de la extinción. Foster observa que la incorporación moderna del Otro cultural se vinculó con el potencial transgresor del inconsciente, asociación primitivista que conectaba los pueblos Ilamados "primitivos" con las etapas primordiales del desarrollo psicosexual. Los surrealistas no sólo apreciaban el arte de estos pueblos por sus valores formales y expresivos, sino que se identificaron intensamente con ellos. Más tarde, y en el contexto del postestructuralismo, resurge esta preocupación por el Otro cultural y se trata de problematizar la distancia crítica con la que este Otro es proyectado. Pensemos en la crítica de Derrida al logocentrismo y de cualquier significado original y trascendental del pensamiento occidental. Sin embargo, Foster observa que este tratamiento queda entre líneas, ya que se sigue idealizando al Otro en su pureza y pocas veces se le deja hablar o se le reconoce como partícipe de una nueva identidad nacional o cultural (cfr. 2001: 216-221). 


\subsection{Le Clézio y el sueño inacabado}

Cuando Le Clézio llega por primera vez a México a mediados de los setenta, no estaba tan predispuesto, como Artaud, a imaginar de antemano lo que buscaba. ${ }^{17}$ Recorre el país, lo estudia y lo incorpora a su subjetividad. Investiga a profundidad la historia y la cultura mexicanas. Su inmersión es más paulatina, prolongada y, podríamos decir, objetiva que la de Artaud. Con más de cuarenta años de distancia entre sus viajes, Artaud y Le Clézio comparten una misma genealogía, la de la crítica del sujeto moderno que encuentra en el Otro, "primitivo" o sobreviviente de la colonización, líneas de fuga que forman parte de una historia y de una geografía que se va reinventando sin cesar, que se proyecta en el porvenir y que vuelve a distintos pasados para constituirse. Ambos comparten el rechazo por la cultura occidental basada en la razón, en la especialización, en la noción de progreso y en la explotación de otros pueblos y de los recursos naturales; la búsqueda de una visión unitaria y armónica del ser humano con la naturaleza; la crítica del individualismo; la escucha de lo inconsciente, las sensaciones y los afectos; y el sueño como estructura poética del pensamiento y de reconstrucción de la realidad. Sueño despierto donde el Yo sale de sí y encuentra al Otro que le revela una vida nueva. Posiblemente la experiencia de Artaud, por la época en la que vivió — dos guerras y la ascensión del fascismo en Europa-y por sus propias condiciones de salud mental y física, fue más violenta, traumática, provocadora e incomprendi-

17 Un importante antecedente y referencia que aborda esta relación entre los viajes a México de Artaud y Le Clézio es el libro de Armando Pereira, Artaud y Le Clézio. Como señala éste, "hay muchas cosas entre ellos (y en) ellos que involuntariamente los asemejan, que los emparentan" y, sobre todo, porque su viaje a México "estuvo dictado por una misma voluntad: escindirse de la cultura europea para buscar en México, en sus culturas ancestrales, lo que Europa ya no les ofrecía" (2011: 7). Armando Pereira dedica en este libro un ensayo a cada autor, adentrándose en los pasos y las obras de cada uno de ellos. En mi texto, mi acercamiento a Le Clézio se ciñe al libro El sueño mexicano o el pensamiento interrumpido y, sobre todo, a "Antonin Artaud o el sueño mexicano" y "Al pensamiento interrumpido de la América india". Más que una profundización en sus viajes y en su obra inspirada por México, pretendo seguir esa pregunta relacionada con las motivaciones de Artaud y sobre las dudas y el misterio que envuelven el viaje del poeta cuarenta años más tarde para los intelectuales franceses. Le Clézio me abrió los ojos a esa genealogía del sueño que también está presente en Carasco y Hébraud y que, paradójicamente, también busca alimentarse de un poco de realidad. 
da. Sin embargo, el sueño mexicano de Le Clézio también condensa una crítica que se construye en las relaciones que establece con otra cultura, con su geografía y naturaleza.

Le Clézio vivió parte de su niñez durante la segunda guerra mundial. En L'Africain, recuerda sus crisis de angustia y la sensación de vivir en un mundo cerrado, sombrío y sin esperanza (2007: 54). Con su madre y parientes sufrió la proximidad de los bombardeos, la falta de medicamentos, las penurias y el miedo. En 1948, cuando tenía ocho años, él y su madre viajaron a África para reunirse con su padre, quien llevaba varios años trabajando ahí como médico. Entonces dejó de padecer migrañas y crisis de cólera para conocer una sensación de libertad intensa y gozosa. De su estancia en África durante aquellos años nace su repulsión instintiva por el sistema colonial. África será el lugar que volverá constantemente a la memoria de Le Clézio. Espacio formado de las sensaciones que se despertaron en él al contacto con esas tierras donde los elementos y fuerzas de la naturaleza eran dioses para sus habitantes y donde la pobreza, la enfermedad y el cuerpo estaban al descubierto. Una tierra original -expresa Le Clézio- donde parecería que el tiempo dio marcha atrás y donde se podría deshacer toda la trama de errores y traiciones de la historia de la civilización occidental (2007: 72).

Más tarde, Le Clézio percibe en la geografía y en la naturaleza misma de México, en su violencia y contrastes, las huellas de las antiguas culturas prehispánicas. En El sueño mexicano o el pensamiento interrumpido escribe diversos relatos sobre la fuerza mágica de la cosmogonía indígena a partir del choque con la civilización occidental. La conquista de México pone al descubierto la confrontación de dos sueños: uno terrestre y pragmático, el del europeo del Renacimiento que busca el oro y explotar la tierra y los pueblos; otro celeste y divino, el del mundo indígena y su ocaso, con sus mitos, la magia y los dioses. Quizá —escribe Le Clézioes con Bernardino de Sahagún que aparece por primera vez en una sociedad occidental ya envejecida, la seducción por los pueblos "primitivos", cuya vida y creencias parecían tan frescas (2000: 69). Tanto colonizadores como vencidos sienten — desde distintas posiciones- aflicción por la pérdida de este mundo y fascinación por las fuerzas dormidas y ocultas del México prehispánico. Éstas dejaron una marca en la memoria y subsisten 
a lo largo de los siglos en leyendas, danzas, fiestas, en la tradición oral y escrita recuperada en códices o en algunos pueblos, como los del norte del país que se mantuvieron más herméticos al contacto con los españoles. Los pueblos Ilamados "bárbaros" de América del Norte —entre los que se cuentan los tarahumaras - eran nómadas, ocupaban un vasto territorio y vivían al margen de los asentamientos de los grandes imperios. Estos pueblos compartían elementos comunes: tenían fama de sanguinarios y aguerridos, vivían de la caza y el pillaje, practicaban un culto solar, hacían uso ritual del incienso y del tabaco, ejercían una religión sin clérigos opuesta a la estructura jerárquica de la iglesia, muchas veces reducida a ritos familiares y ceremonias chamánicas, y utilizaban plantas alucinógenas para entrar en contacto con las fuerzas sobrenaturales. Estos pueblos "bárbaros" e indómitos sobrevivieron a la colonización sufriendo distintos grados de aculturación. Sus cualidades y formas de vida despertaron la imaginación del mundo "civilizado". Fascinación que Le Clézio llama "el sueño bárbaro" y que se prolonga hasta el siglo xx alimentando el sueño de Artaud.

En el texto "Artaud o el sueño mexicano" incluido en El sueño mexicano, Le Clézio señala que, en la época contemporánea, Artaud fue el primero en vivir en tierras mexicanas ese sueño del paraíso perdido, en una mezcla de violencia y misticismo. Él soñaba con un pueblo que practicara un culto solar, la curación con plantas, la magia, los sacrificios y los ritos del peyote. Y, al parecer, lo encontró. No obstante, Le Clézio expresa la posibilidad de que Artaud nunca hubiera Ilegado a la Sierra Tarahumara. En teoría, partió en compañía de una misión oficial de antropología de la que no se guarda ningún registro. Por lo tanto, si partió debió haberlo hecho solo y las dificultades eran grandes. En esa época ya existía el tren que llegaba a la Sierra, pero para llegar a Norogáchic — población donde Artaud participó en el rito del peyote- había que atravesar barrancas profundas a caballo; Artaud estaba enfermo y disminuido por las drogas; no hablaba castellano (o poco) ni la lengua de los tarahumaras. Además, el pueblo de Norogáchic estaba bajo la protección de la misión jesuita y Le Clézio no entiende cómo Artaud, apóstata del paganismo, podía comunicarse con los indios o asistir a las ceremonias de peyote. Artaud tuvo a su alcance suficientes libros para describir a los tarahumaras, el paisaje y los ritos sin haber estado nunca ahí. En sus escritos se entremezclan reminiscencias muy distantes en 
el tiempo y en el espacio, como el mito de los Atlantes, la antigua cultura egipcia, la pintura anterior al Renacimiento, la leyenda de los Reyes Magos o los signos de la Cábala. Sin embargo, esta incertidumbre no rompe el encanto de su aventura; posiblemente le dé un toque de sentido común o de "realidad". Quizás refuerza la idea de que el sueño de Artaud era sobre todo suyo, un reflejo de sus propias ideas, luchas y preocupaciones. Para Le Clézio, el problema de la autenticidad de la experiencia de Artaud no tiene sentido y destaca que, para éste, describir el rito del peyote significó dar cuenta de un encantamiento, de un hechizo que lo transformó completamente, que lo volvió otro (Le Clézio 2000: 225-226). El rito del peyote supuso la revelación de la poesía en un estado puro, creación fuera del lenguaje y teatro original (Le Clézio 2000: 226). Cuando vuelve a Francia, Artaud se obsesiona con la idea de la magia y de que ha sido hechizado. Ello lo lleva a encerrarse en sí mismo. Sus palabras y gestos pasaron a formar parte del registro de la locura. Fuera de la Sierra, su experiencia iniciática y curativa se convirtió en delirio y aislamiento.

En otro texto de El sueño mexicano, "El pensamiento interrumpido de la América india", Le Clézio se pregunta qué hubiera sucedido si las culturas indígenas de América no hubieran sido destruidas. ¿Cómo hubieran evolucionado, qué filosofía y conocimientos hubieran podido enriquecerlas? O, ¿qué saberes, que estaban en la base de la mayor parte de las sociedades amerindias, permanecen y cuáles hubieran ayudado a resolver contradicciones del mundo occidental? Le Clézio piensa en la armonía entre el ser humano y la naturaleza, el equilibrio entre el cuerpo y el espíritu, la unión de lo individual y de lo colectivo que, desde sus apreciaciones de estudioso de las culturas amerindias, formaban parte integral de su cultura y de su relación con el mundo. A su modo de ver, las prácticas del trance o de la revelación hubieran podido aportar algo a la armonía entre lo natural y lo sobrenatural. El respeto de las fuerzas de la naturaleza hubiera dirigido un equilibrio entre el ser humano y el mundo. La herencia del chamanismo hubiera podido integrar el sueño y el éxtasis en lo cotidiano. No es por azar que la civilización occidental del siglo xx recurriera a los temas filosóficos y religiosos de los indígenas de América para intentar recuperar un equilibrio perdido. Y este es también el afán de Le Clézio, quien enlaza su historia personal, el reencuentro en otra geografía de la 
fuerza que África despertó en él y que lo llevó a percibir la vida, no con nostalgia, sino desde el sueño, un sueño despierto donde hay un diálogo constante con la naturaleza, las huellas del pasado, la pérdida, la destrucción y probablemente la culpa de pertenecer a una cultura que colonizó y exterminó a otras.

\subsection{Carasco, Hébraud y el "poder del ver"}

Paralelamente, Raymonde Carasco y Régis Hébraud realizaron entre 1976 y 2003 una serie de viajes y de películas sobre las prácticas culturales y la vida cotidiana de los tarahumaras. Ellos partieron a la Sierra Tarahumara con la intención de seguir los pasos y los textos de Artaud, de confrontarlos con la realidad y con su propia mirada emprendiendo así una investigación de carácter histórico, ético, artístico y filosófico. En esta empresa conjunta, Raymonde Carasco se encargaba de la escritura y dirección, mientras que Régis Hébraud operaba la cámara y registraba el sonido. Ambos llevaban a cabo la edición y la producción. Realizaron trece películas y una serie compuesta por cinco cortometrajes. Cabe destacar que partieron financiados por sus propios recursos y sin ningún compromiso institucional ni disciplinario que cumplir. Hébraud estudió matemáticas e informática y se dedicaba a la enseñanza. Carasco tenía una formación universitaria en historia de la filosofía y desempeñaba en Francia labores académicas y docentes. En su trabajo intelectual podría hablarse de un salto de la teoría a la práctica, es decir, a la experimentación de la escritura de Artaud y de sus propias inquietudes en un ejercicio cercano al del antropólogo pero sin abandonar una perspectiva estética, cinematográfica, literaria y filosófica propia. Los textos de Artaud representaron para ellos un terreno a explorar y un saber poético a trabajar que sobrepusieron al territorio de la Sierra Tarahumara, a sus propias experiencias en ella y a su trabajo fílmico. Éstos no siempre están presentes en sus obras ni en la percepción de las vivencias cotidianas que Carasco anotaba en unos cuadernos de viaje. ${ }^{18}$ Por momentos los olvidan, inmersos en su

18 Los cuadernos tarahumaras de Raymonde Carasco fueron editados por Régis Hébraud y publicados en 2014 bajo el título Dans le bleu du ciel. Au pays de Tarahumaras 1976-2001. 
aventura personal. Sus relecturas suceden en distintas épocas y muchas veces están determinadas por hechos concretos como hallazgos en el paisaje, conversaciones con sus amigos tarahumaras o ausencias largas en la Sierra. Con el paso del tiempo y después de varias estancias en el pueblo de Norogáchic, Carasco expresa que ya no se siente extranjera pero acepta la diferencia. No se siente ni dentro ni fuera, sino más bien captada por la fuerza de este pueblo y por la atmósfera del lugar (cfr. Carasco 2014: 234). También observa un cambio en su manera de concebir al "tarahumara". Su deseo inicial de encontrar al tarahumara puro, sin influjo blanco, se transforma a lo largo de los años con los lazos de amistad que entabla, especialmente con el chamán o raspador Ceverico. Esta amistad la lleva a descubrir la infinita distancia del Otro y su propia fuerza, sin la necesidad inicial de proyectar sobre él una imagen idealizada.

Carasco describe su experiencia tarahumara como un camino de iniciación en el que se van adentrando paulatinamente en el rito más hermético y sagrado de los tarahumaras, Jíkuli o rito del peyote. Sus primeras películas nacen de la observación y apreciación del paisaje y de las costumbres y gestos cotidianos de los tarahumaras que apuntan a su intimidad con la naturaleza y a su fuerza. Posteriormente, una progresiva familiarización con los habitantes de Norogáchic y con el territorio da lugar a la filmación de ritos y fiestas estacionales a los que son invitados, como son el Yumari y Tutuguri, rituales de petición y de agradecimiento por las cosechas, la Iluvia, la buena salud o la llegada del buen tiempo. En sus cuadernos tarahumaras, Carasco se pregunta de qué forma y a partir de qué elementos puede dar cuenta de un rito y de su desarrollo; ya que, para ella, ninguna cámara podrá filmar la intensidad de la fiesta y de la danza. Así, explica que primero empieza por la sensación, el afecto y la percepción que le provoca la atmósfera. De ahí, experimenta el deseo de filmar, de volver visible esta "pequeña sensación", la sensación del acontecimiento inicial interno: inaprehensible, inasible e invisible (Carasco 2014: 307). Su trabajo no consiste en restringir la comunicación del rito al registro objetivo de la cámara cinematográfica, sino en sentir, captar y hacer visibles las fuerzas de la atmósfera ritual, como lo hace el chamán.

De su amplia filmografía, me referiré a dos películas: Ciguri 99. Le dernier chaman (Carasco y Hébraud 1999) y Raspador/le sueño de la serie La 
fêlure du temps (Carasco y Hébraud 1999), con el fin de incorporar ese sueño propio del pensamiento chamánico que ha fascinado a artistas e intelectuales occidentales, desde dos vertientes que en la obra de los cineastas terminan por integrarse. En el primer filme, Carasco y Hébraud sobreponen el relato de "El rito del peyote entre los tarahumaras" de Artaud a imágenes filmadas durante las ceremonias rituales y al paisaje de la Tarahumara. Ciguri 99 emerge de un triple sueño, el del relato de Artaud, el del montaje de las imágenes de los cineastas y el de las palabras de Ceverico, raspador o chamán del peyote y amigo de los cineastas. En el segundo filme, Carasco entabla una serie de diálogos con Ceverico sobre su historia como raspador y sobre el sueño chamánico, que se alterna con imágenes del desarrollo del rito. Aquí es la palabra del Otro la que se escucha.

En Ciguri 99, el relato de Artaud y el montaje de las imágenes del rito no se corresponden de una forma literal, sino que funcionan como una suerte de invocación o aliento que ejerce uno sobre el otro. Su relación se expresa en la atmósfera, en las sensaciones que provocan los distintos encuadres y que parecen conjurar una sensibilidad de lo sagrado o de fuerzas que el ser humano no puede dominar pero sí captar: la disposición del círculo ritual, la oscuridad y las sombras, el fuego de las hogueras, la música de la raspa, ${ }^{19}$ de los tambores y de las campanitas, las danzas y figuras que realizan los participantes y que recrean el movimiento cósmico, la ofrenda, el frío y el viento, la atención en los gestos y en las partes del cuerpo, el vestuario y los utensilios empleados, las distintas etapas del rito como la purificación del cuerpo mediante la limpia y el humo o los trazos que dibuja en el aire el chamán con su cuchillo en momentos específicos, la toma del peyote, las risas, los murmullos, la borrachera, el canto suave del raspador. Todo ello se va fundiendo con la lectura del texto de Artaud, como si sus visiones y reflexiones abrieran el resquicio de un lenguaje misterioso del que emerge otro plano que otorga cualidades originales a los actos y cosas percibidas. Así, como observa Carasco, la puesta en escena del rito de la raspa pone en acción dos principios: el del cuerpo y su energía, y el del trabajo del pensamiento del raspador (Carasco 2014: 311).

19 Nombre de la ceremonia del peyote y del instrumento musical que se emplea en dicha celebración. 
Carasco busca integrar la experiencia del pensamiento durante el sueño chamánico en el contexto de una reflexión filosófica de su tiempo, concretamente en el escenario intelectual francés de los ochenta y noventa. En sus cuadernos tarahumaras hace referencia a los escritos de Deleuze, Foucault o Blanchot. Carasco imagina una posible iniciación. Ceverico le transmite el pensamiento-Jíkuri permitiéndole filmar y participar en las ceremonias, haciéndole la demostración de un rito y dialogando con ella sobre su vida como raspador. Ambos, él como raspador y ella como cineasta, comparten un saber en común que ella identifica como "la experiencia del ver" (Carasco 2014: 242). Esta experiencia se compone de un doble saber: el "poder de ver" y el de mostrar. El "poder de ver" implica un "salir de sí" —un sortir en moi-como sugiere Artaud (2014: 42), donde el cuerpo se reorganiza y se reconstruye en un nuevo proceso de subjetivación. En el caso de Carasco este paso se realiza a través de la palabra y el pensamiento de Ceverico, así como de su percepción de la atmósfera del rito.

Cuando Ceverico se refiere al sueño, lo que Ilama el "poder de ver", Carasco apunta a que alude a un trabajo del pensamiento y especifica: "Le pouvoir de voir est de voir dans les rêves" (Carasco 2014: 239); ;0 consiste en ver visiones como si fueran las cosas mismas bajo la fuerza del peyote. En sus cuadernos tarahumaras y en Raspador/le sueño, Carasco reproduce los diálogos que entabla con Ceverico sobre su vida como raspador. Ceverico explica que en un primer momento hace una evaluación de los síntomas del paciente, quien le cuenta también su sueño. En esta etapa funciona más como sanador o curandero. Luego se organiza una raspa. Durante el rito, el raspador puede ver el sueño del enfermo en el sueñovisión que tiene: sueño del sueño. Ceverico busca una palabra para referirse a este ejercicio y habla del "trabajo del sueño": "Le travail du rêve est un travail de la pensée. Un pensamiento. Le voir est une pensée, le travail même de la pensée", puntualiza Carasco (2014: 272). ${ }^{21}$ A partir del diálogo que entabla con el enfermo sobre su sueño, surgirá el pensamiento del sueño bajo la acción de líkuri. Carasco intuye: "Il y aurait donc, chez les raspadores Tarahumaras, une pensée-image plus proche peut-être de celle

20 "El poder de ver es el de ver en los sueños" (la traducción es mía).

21 "El trabajo del sueño es un trabajo del pensamiento. Un pensamiento. El ver es un pensamiento, el trabajo mismo del pensamiento" (la traducción es mía). 
du cinéaste que de l'interprétation des psychanalystes" (272). ${ }^{22}$ En este sentido, habría que situar la separación de dos planos. Por un lado, una conciencia personal y, por otro, un plano de conciencia donde es Otro el que habla al raspador. Tiene lugar una integración entre realidad cotidiana y realidad de ese otro plano de conciencia-Jíkuri. Para Carasco, este trabajo de separación es más sutil que las oposiciones entre lo real y lo irreal, lo real y lo imaginario o la conciencia y lo inconsciente (308).

En sus cuadernos tarahumaras, Carasco señala que el sueño es como una casa por construir (Carasco 2014: 310). En Raspador/le sueño aparecen imágenes de muros, ya sea en construcción, casas o ruinas, desde los más antiguos hechos de piedra hasta los más modernos de tabiques y líneas rectas. Es como si el sueño, que se desarrolla en lo concreto sobre la disposición del círculo ritual, también fuera una puesta en escena construida a partir de fuerzas y de los elementos del entorno natural y humano a fin de crear un espacio de visión y de morada. Para Carasco, el trabajo del sueño es la fuerza de la visión que se erige como auto-afirmación, como mundo. El vidente, que puede ser el chamán, el poeta o el profeta es el mediador creador del mundo del sueño o del mundo como sueño en el que lo real y el sueño son indiscernibles. El chamán invierte las fuerzas de lo real, afirma, como el artista, las fuerzas de lo falso como realidad, la única realidad. Lo irreal es productor de realidad (Carasco 2014: 307). En este sentido, el chamán es artista, hace que los otros crean en un mundo. Da a ver lo invisible mediante otro tipo de visión que no se limita al ojo como órgano y que podría llamarse visión-pensamiento.

Para Carasco, la fuerza del pensamiento tarahumara radica en la imbricación de la cuestión del cuerpo y del problema del pensamiento. Parte del trabajo de iniciación del raspador consiste en aprender a ver el ser del peyote, que es otro cuerpo. El mundo de Jíkuri no es un mundo trascendente e ideal, del que la sociedad tarahumara sería una copia no original. Los dos mundos son inseparables. Jíkuri no es un dios, es un ser de poder que el dios creador dio a los tarahumaras para ayudarlos. Posee una doble realidad, como cactus que crece en el desierto y como ser de poder.

22 "Podría hablarse, en el caso de los raspadores tarahumaras, de un pensamientoimagen más cercano al del cineasta que al de la interpretación de los psicoanalistas" (la traducción es mía). 
Cuando un chamán es requerido para una curación, primero examina el cuerpo del paciente y puede distinguir la enfermedad como una mancha. Esta enfermedad no es un desorden del Yo sino del mundo que golpea al azar, como la peste. El poder del sueño radica en ver ese otro cuerpo a través del encuentro con Jíkuri. El cuerpo del que habla el tarahumara es una experimentación, una creación en acto. Y este cuerpo, se hace y se rehace, como "el cuerpo sin órganos" de Artaud, ${ }^{23}$ creación necesaria para experimentar otro cuerpo, para construir otra realidad y librarse de sus automatismos. Para Carasco, el tarahumara experimenta también un "cuerpo sin órganos", lo construye y lo vive de otra manera, a través de una puesta en escena estricta del rito, en un saber increado del infinito y donde la vida y la muerte son pensados en un mismo plano de inmanencia (Carasco 2006: 140). Proceso de resubjetivación a partir de un viaje al Otro mediante el acto ritual y —en el caso de Carasco y Hébraud- a través del cine, que puede pensarse también como otro cuerpo. Este sortir en moi, no sobreviene saltando un muro por encima de la percepción ordinaria, sino atravesando esta percepción de la vida cotidiana para extraer los perceptos y los afectos singulares. Así, las imágenes se vuelven visiones, intensidades de luz y color extraídas de las texturas, de las líneas de los caminos y de los materiales, sensaciones que provienen del movimiento del cuerpo, del descubrimiento de sus recovecos, de sus fragmentos y de su extenuación. Recurriendo a Artaud, Carasco llama a este trabajo de creación la experimentación-Jíkuri, afirmación decisiva de una nueva forma del pensamiento, que representa un problema nuevo en las fronteras del arte y de la filosofía (Carasco 2006: 141).

\section{$* * *$}

En este itinerario, la poesía no se limita al lenguaje humano. Es anterior y exterior a él, está estrechamente ligada a la vida y al ritmo de la naturaleza, a una sensibilidad de lo sagrado imaginada en otros pueblos y se filtra a través de la desintoxicación del cuerpo, que se libera de las determinaciones

23 La fórmula de un "cuerpo sin órganos" fue desarrollada por Deleuze y Guattari (2015) en el texto "28 novembre 1947 ¿Comment se faire un corps sans organes?" -incluido en Mil mesetas - a partir del texto radiofónico de Artaud, Para acabar con el juicio de dios, grabado precisamente en esta fecha y que nunca llegó a emitirse. 
que le han impuesto el Yo y la sociedad, para acceder a un rito nocturno de aniquilación y renacimiento. Se percibe como una fuerza que se manipula mediante el poder del sueño. Un sueño que devuelve a la realidad, a una realidad siempre abierta a la renovación, a la salida del Yo hacia lo infinito a través del encuentro con el Otro. Viaje fuera del texto hacia lo invisible o lo real y hacia el referente, mediante una especie de trabajo de campo. Este acto poético puede ser gesto, grito, visión-pensamiento, palabra, movimiento, intensidad lumínica, balbuceo o desvanecimiento. Artaud, Le Clézio, Carasco y Hébraud: ven a la luz de otra realidad los sueños de su propia cultura. Así, pensar desde afuera, en sus límites, el sentido y la práctica del arte, la literatura o el teatro, es otorgarles una nueva vida, un nuevo sistema de referencias que alimente su reflexión y su fuerza.

\section{Bibliografía}

Acuña Delgado, Ángel. "Jíkuri y bakánowa: rituales de vida y muerte en la Sierra Tarahumara", en AIBR. Revista de Antropología Iberoamericana, 4.1 (2009): 54-83.

ARTAUD, ANTONIN. El teatro y su doble. Trad. Enrique Alonso y Francisco Abelenda. Barcelona: Edhasa, 2001.

Artaud, Antonin. OEuvres. Évelyne Grossman (ed.). París: Gallimard, 2004a.

Artaud, Antonin. México y Viaje al país de los tarahumaras. México: Fondo de Cultura Económica, 2004b.

Artaud, Antonin. Los tarahumaras. Trad. Ariel Dilon. Buenos Aires: El Cuenco de Plata, 2014.

Borie, Monique. Antonin Artaud, le théâtre et le retour aux sources. Mayenne: Gallimard, 1989.

Bradu, Fabienne. André Breton en México. México: Fondo de Cultura Económica, 2012.

Brunel, Pierre. Théâtre et cruauté ou Dionysos profané. París: Librairie des Méridiens, 1982.

Carasco, Raymonde. "Approche de la pensée tarahumara", en Antonin Artaud. Guillaume Fau (dir.). París: Bibliothèque National de France / Gallimard, 2006. 134-141.

Carasco, Raymonde. Dans le bleu du ciel. Au pays de Tarahumaras 1976-2001. París: Régis Hébraud / Éditions Nouvelles François Bourin, 2014.

Carasco, Raymonde y RéGIS HéBraud [película]. Ciguri 99-Le dernier Chaman [DVDROM], Francia, 65 min., color, 1999.

CARAsCo, Raymonde y RéGIS HéBraud [película]. Tarahumaras 2003-La fêlure du temps: Raspador-Le sueño [DVD-ROM], Francia, 46 min., 16 mm, color, 2003.

Deleuze, Gilles y Félix Guattari. Mil mesetas: capitalismo y esquizofrenia [1980]. Trad. José Vázquez Pérez y Umbelina Larraceleta. Valencia: Pre-Textos, 2015. 
EliAde, Mircea. "Permanencia de lo sagrado en el arte contemporáneo", en El vuelo mágico y otros ensayos. Trad. Victoria Cirlot y Amador Vega. Madrid: Ediciones Siruela, 2005. 139-144.

Flores, EnRIQue. "Artaud y el rito de los reyes de la Atlántida", en Literatura Mexicana. México, X.1-2 (1999): 187-224.

Flores, EnRIQue. “¿A qué vino Artaud a México?”, en Revista de la Universidad de México, 14 (abril 2005): 34-40.

Foster, Hal. El retorno de lo real. La vanguardia a finales de siglo. Trad. Alfredo Brotons Muñoz. Madrid: Akal, 2001.

Grossman, Évelyne (ed.). Antonin Artaud. OEuvres. París: Gallimard, 2004a.

Le Clézıo, J. M. G. Diego y Frida. Una gran historia de amor en tiempos de la revolución. Trad. Mauro Armiño. Madrid: Ediciones Temas de Hoy, 1994.

LE ClÉZıO, J.M. G. Le rêve mexicain ou la pensé interrompue. La Flèche: Gallimard, 2000.

Le ClézıO, J. M. G. L’Africain. París: Gallimard, 2007.

Le Clézıo, J. M. G. El sueño mexicano o el pensamiento interrumpido. Trad. Mercedes Córdoba y Tomás Segovia. México: Fondo de Cultura Económica, 2008.

Pereira, Armando. Artaud y Le Clézio. México: el país de lo imposible. México: Universidad Nacional Autónoma de México, 2011.

Sariego Rodríguez, Juan Luis. "La cruzada indigenista en la Tarahumara", en Alteridades. México, 24 (2002): 129-141.

SChNeIder, Luis Mario. "Artaud y México", en Antonin Artaud. México y Viaje al país de los tarahumaras. México: Fondo de Cultura Económica, 2004.

Sollers, Philippe (dir.). Artaud. Trad. Ana Aibar Guerra. Valencia: Pre-Textos, 1977.

Todorov, Tzvetan. Nosotros y los otros. Trad. Martí Mur Ubasart. México: Siglo XXI, 2007.

VARINIA Nieto SÁNCHEZ

Hizo sus estudios de Licenciatura en Letras Hispánicas y de maestría en Literatura Comparada en la UNAM. Obtuvo un máster y un doctorado en Humanidades en la Universidad Pompeu Fabra, Barcelona. Actualmente realiza una estancia posdoctoral con beca del Conacyt en el Departamento de Lenguas y Literaturas Modernas y Estudios Ingleses de la Universidad de Barcelona, donde lleva a cabo una investigación sobre la noción de identidad desde el paradigma del Otro cultural y a través de una interpretación del paisaje en los textos mexicanos de Antonin Artaud y en las películas de los cineastas franceses Raymonde Carasco y Régis Hébraud. Ha publicado "La obscenidad del amor: Nan Goldin y Roland Barthes. Figuras y fragmentos del discurso amoroso a finales del siglo xx" (2015) y "'Escrituras del ver': viajes al país de los tarahumaras" (2018). 